\title{
Walk, talk and draw: Fieldwork in nature to unpack the complexities of sustainability.
}

\author{
Elisa Bertolottia, Valentina Vezzani ${ }^{b}$, \\ art \& Design Department, Universidade da Madeira; ID+ Research Unit; ITI/Larsys \\ ${ }^{b}$ Art \& Design Department, Universidade da Madeira; ID+ Research Unit; Paco Design Collaborative \\ *Corresponding author e-mail: elisa.bertolotti@staff.uma.pt ; vvezzani@staff.uma.pt
}

\begin{abstract}
:
Atlantic Wonder (AW) is a platform of multidisciplinary conversations and creative activities that reflect upon the relationship between design and nature and which emerged out of collaborations between designers and natural scientists on the island of Madeira. AW explores the role of design as mediator between disciplines and areas of study and practices that concern nature. Madeira acts as a testbed for regenerative innovations within this context, in order to achieve sustainable transformations. The paper investigates the relationship between design for sustainability and nature through the application of tools and fieldwork exercises used during the AW Summer School in 2019. The paper reflects upon the need for designers to be in contact with nature in order to learn about the complex interconnections that exist between living beings and their habitat. The aim is to contribute to a new dialogue about design for sustainability.
\end{abstract}

Keywords: design for sustainability; learning-by-walking; design tools; design as bridge

\section{Design as a bridge on an island of complexities}

Sustainability and sustainable development are global goals; they are contemporary challenges for investigators, educators, industry, policy makers and communities worldwide. Exploring how to sustainably balance the needs of the environment, economy and society is the object of discussion for many disciplines and research paths. However, it is very difficult to identify efficient and effective strategies to design and implement sustainable interventions or transformations. The field of design for sustainability is understood in various ways but the description below outlines its complexities and challenges:

This emerging field is considered to be transdisciplinary; it learns from and contributes to multiple and expanding areas of theoretical and practice-relevant literature. These include but are not limited to: collaborative and participatory design, policy design and design for government, systemic design, more-than- 
human design, decolonial and pluriversal design, indigenous and non-Western ontologies and epistemologies, solution-oriented sustainability science, sustainability transitions, complex systems theories, futures studies, transformative sustainability innovation in business, practice theory, alternative economies, critical urban research and feminist theory. (Gaziulusoy et al., 2021)

Today we see design attempting to build bridges between disciplines, perhaps more than ever before, in order to contribute to sustainable development and sustainability transformations (Gaziulusoy et al., 2021). However, the challenge in understanding and solving complex issues is not easily solved because of the way in which contemporary knowledge has become increasingly specialized. Morin (2017) says that in order to fully comprehend fundamental global problems, it is necessary to develop a broad, unified common knowledge that can help us to build links between specific fields of study, disciplinary approaches and areas of expertise that would otherwise remain separated, compartmentalised and segregated. We need to find ways to link different types of knowledge once we have identified them. It therefore becomes essential to reformulate education (Morin 2017; Rancière, 2008), rethink the idea of mediation (Bruni, 2018) and question our ways of collaborating creatively (Escobar, 2018).

Citizen science is an example of methodology developed to address the separation and isolation between disciplines. In particular, it involves non-experts to contribute to ongoing research activities by sharing their own observations and data collection techniques with the support of scientists from different areas of study. Citizen science experiences can also expand beyond a formal contribution to a specific research project in terms of data collection. The approach can allow participants the opportunity to learn about scientific literacy and contribute to a society in which conversations on complex issues are better informed (Bonney et al, 2009; Dickinson et al, 2012; de Vries et al, 2019).

To become more aware, we must develop our own ecological literacy (Boehnert, 2018). When designing for sustainability, as with educating for sustainability, it is necessary to learn what nature really is, understanding how human beings live within it and depend upon on its vital resources, systems and cycles. In other words, we should first consider how humans exist within a web of living co-vulnerabilities (Puig de la Bellacasa, 2017) before designing.

Starting from the basics helps us to understand the need to adapt the way we live, work, design, produce: we must dedicate time to exploring, discovering, touching and experiencing nature. Through this process, design can act as an engine to activate social conversations that allow nonexperts and policy makers to engage with nature. In particular, design can be used as a tool for us to become more aware and motivated to protect the various elements and ecosystems that contribute to the complex organic system that is nature.

Madeira is a small island in the Atlantic Ocean that is, in many ways, a precious relic of the natural environments that could be found on ancient Earth. Today the island is experiencing a rapid period of construction and transformation, and there is little local dialogue, interaction and sharing of knowledge about sustainable development currently taking place. As such, the location and its context were of particular interest to this study.

We believe that designing with care is key (Puig de la Bellacasa, 2017). This means that designers must learn to change their perspectives and move beyond a human-centred approach (Tsing, 2015; Haraway, 2016; Mancuso, 2019; Escobar, 2018; Braidotti, 2019; Coccia, 2020; Latour, 2018 \& 2021). As designers and educators based in Madeira, we initiated our research by attempting to understand the local context in various areas including: higher education and scientific research; scientific dissemination provided by museums; local authority policy; land and resources management and 
social conversations at community level. Beyond this, in 2018 we organised an international summer school where local experts, foreign scholars and creatives met with each other. Our goal was to start mapping the complex network of issues and conversations about nature and sustainability currently taking place on the island. We learnt that in order to disentangle these complexities we must spend more time in the field in order to appreciate and reconnect with the natural environment. Through these experiences we developed a fieldwork approach and set of related tools to learn about nature, within the context of design.

\subsection{Madeira Island: contextualising the need for positive conversations about nature}

A Portuguese territory with an independent government overseeing the management of lands and resources, Madeira Island is part of Macaronesia, a relict area containing Tertiary era species, which were made largely extinct in Europe during ice ages (Sziemer, 2010). The peculiar landscape and climate conditions in different areas of the island contribute to various types of natural ecosystems in which several endemic species continue to exist: some with ease, and some with difficulty. Today, we can easily observe the impact of human interventions that have taken place over centuries and understand the struggle that some endemic plants face in order to survive, under pressure from pollutants and the introduction of other invasive species. For instance, the Laurel Forest or Laurissilva, is the largest Macaronesian Laurel Forest in the world, now covers only $20 \%$ of the island's surface.
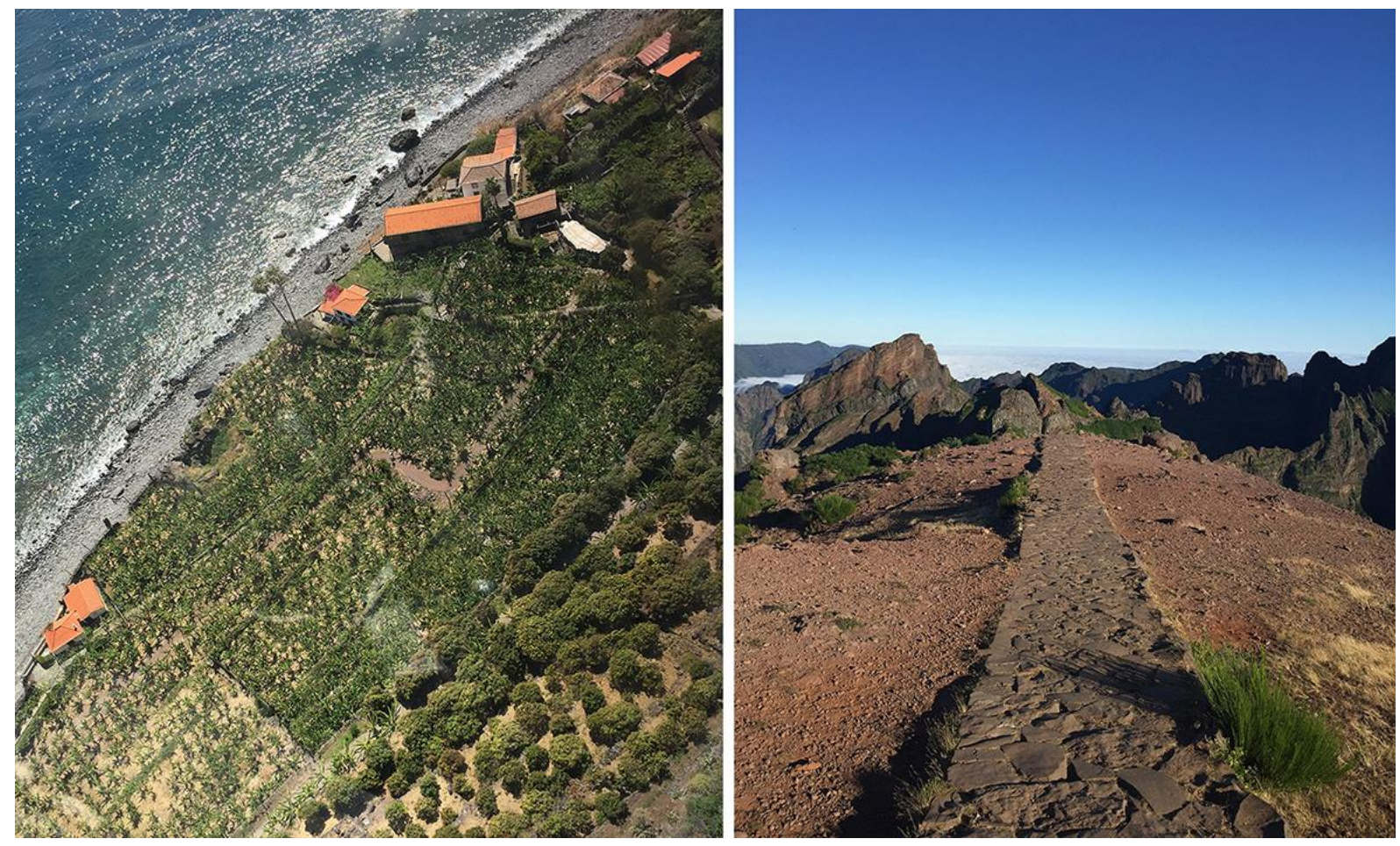

Figure 1. Faja dos Padres and Pico Ruivo (1862mt). The special morphology of Madeira, which includes peaks, steep valleys and dramatic cliffs, influences the local climate and the existence of diverse natural ecosystems.

The natural landscape changed radically and drastically from when human beings first settled on the island: more and more portions of forest were cut down to provide construction material and create space for farming activities and housing. In order to support agriculture, two types of large-scale infrastructure were also developed. Firstly, tunnels were excavated by hand through the hard 
volcanic rock to open faster walkable routes between mountain valleys. Secondly, watercourses, referred to as levadas, were built to bring water from the mountains down to the agricultural lands.

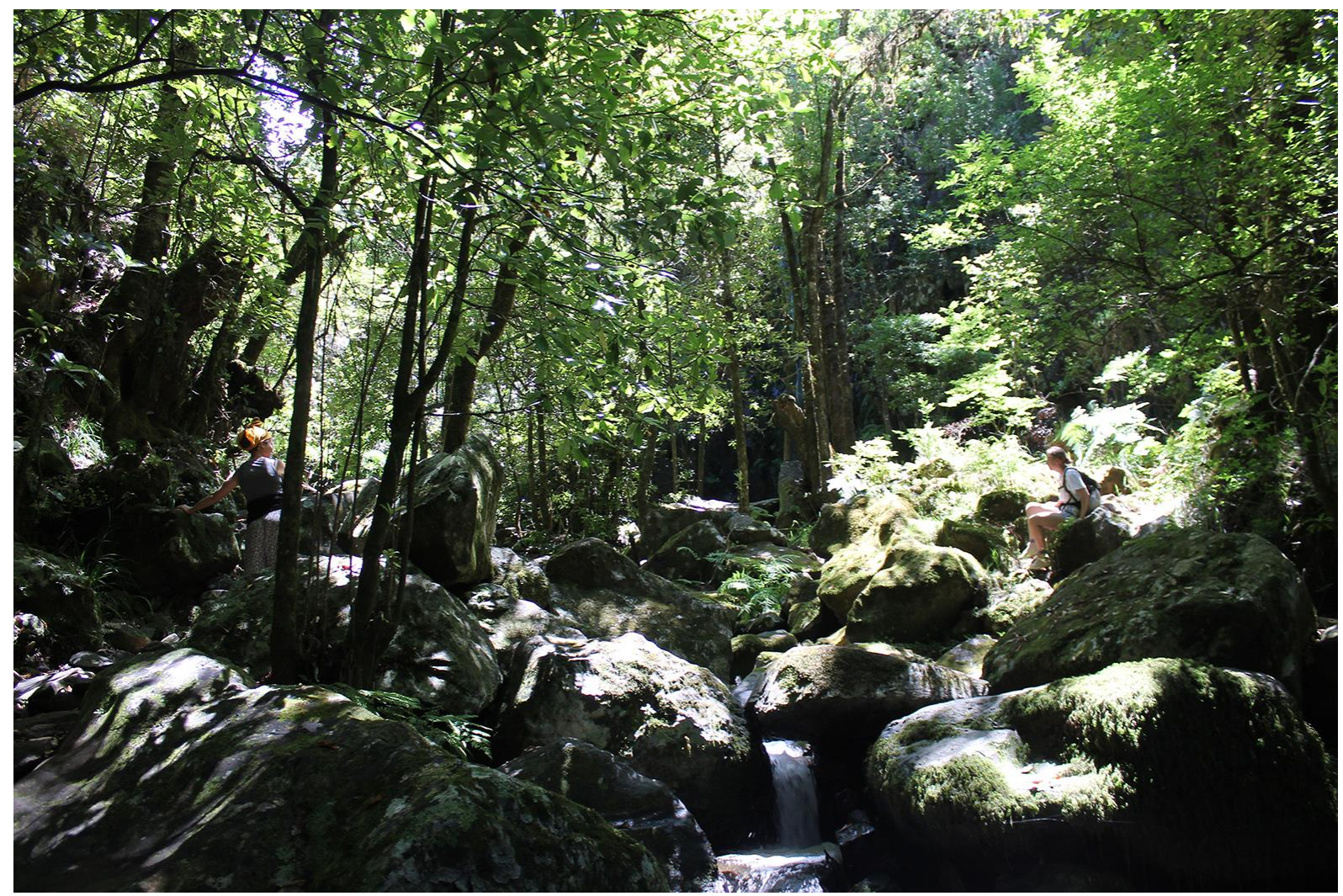

Figure 2. Laurissilva, UNESCO world heritage site since 1999. Laurel Forests are humid forests, heavily influenced by the mist, growing in the cloud zone of the island. About twenty different species of trees grow in the Laurel Forest, only four of them belong to the laurel family - Lauraceae. Many of the plant families growing in the Laurel Forest are very old and evolved as early as the Upper Cretaceous period (100 million years ago), along with did the Laurel family itself. During the Tertiary age, Laurel Forests covered large parts of Europe. As the climate cooled off during the Tertiary period in Europe, Laurel Forests withdrew to the south until they finally became extinct. The trees forming the Macaronesian Laurel Forests of today are only a small section of the former European ones. Before human beings set foot on the island in 1419, about 793 different fern-related and flowering species grew naturally on Madeira. Since then, around 540 plant species have been introduced: some have been planted for food, some as ornaments, some for quick and efficient wood production. These new species are a serious problem because some have become very aggressive immigrants, invading deep into the Laurel Forest and into steep ravines which are difficult to reach and manage (Sziemer, 2010).
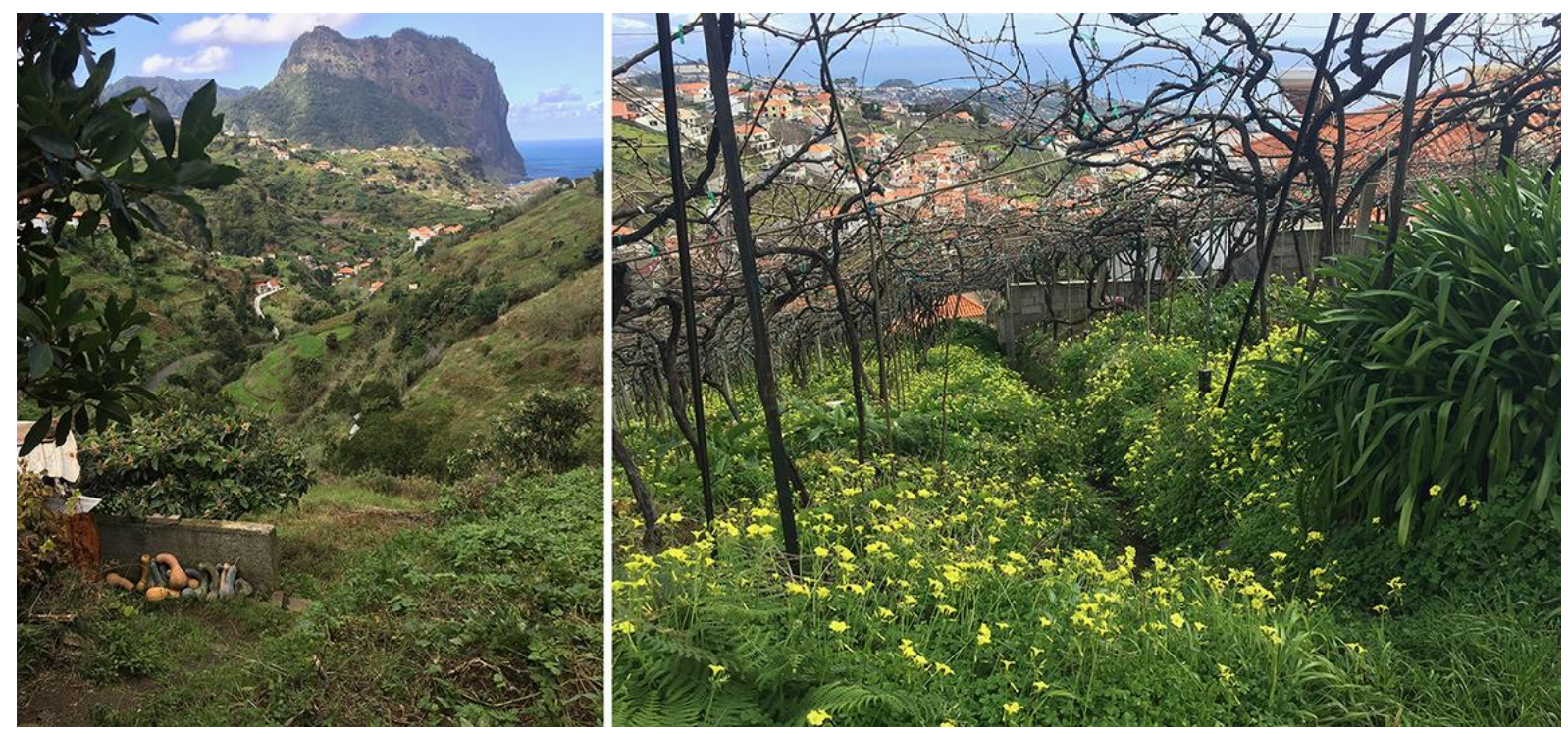
Figure 3. A typical rural landscape of Madeira. Sugarcane, introduced in 1452, was for a few centuries a precious crop for the economy of the island, but also very demanding in terms of the land and natural resources that were needed to produce sugar. From the mid-16th century vineyards started to replace sugarcane for the production of the renowned Madeira wine, while bananas were introduced in 1925. Today grapes and bananas are still very important for the economy of Madeira.
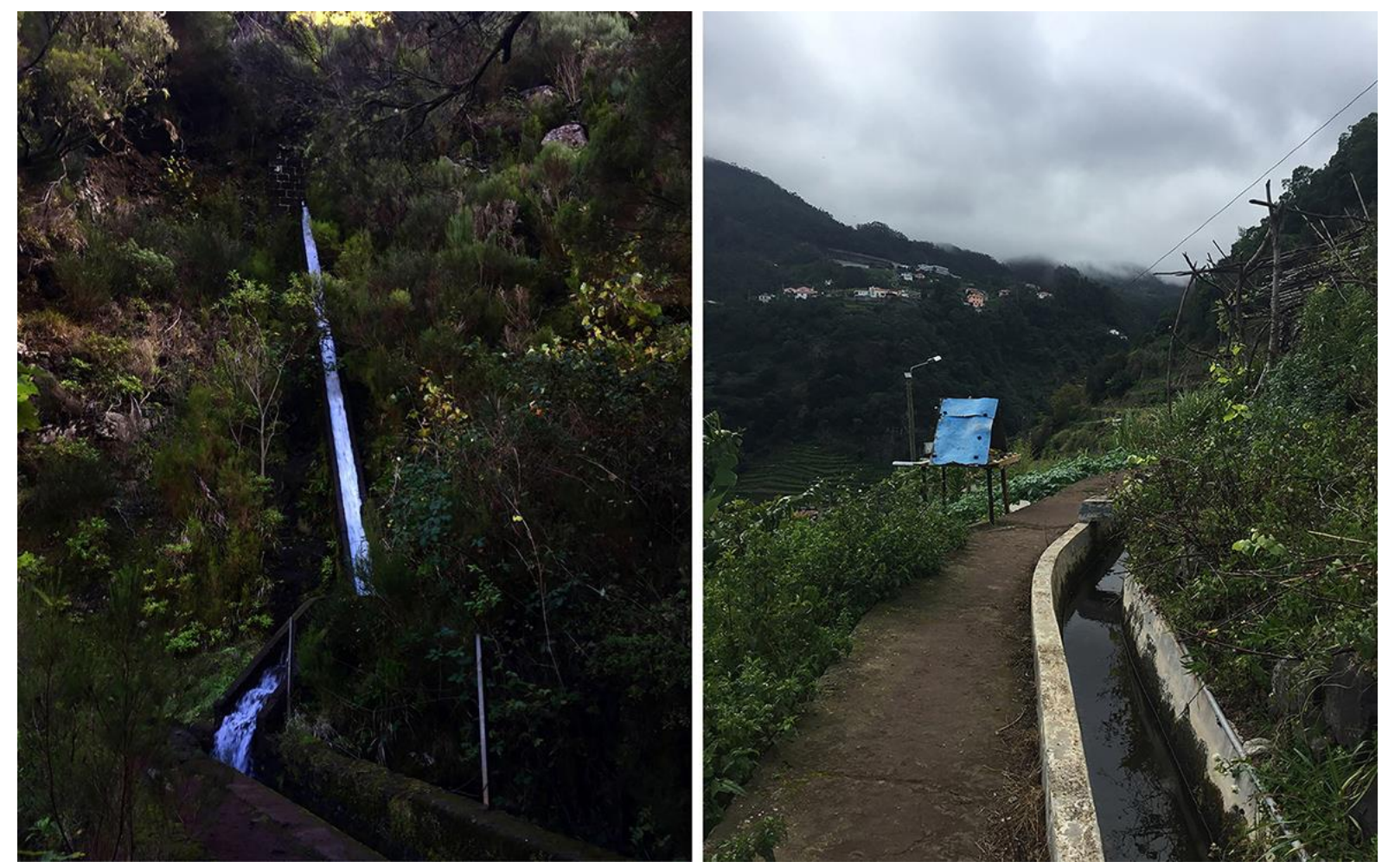

Figure 4. The systems of 'levadas'. These artificial water paths are today one of the most popular attractions for many visitors to the island. Until agriculture became the driving economy for Madeira, around one quarter of the island's total surface used to be allocated to farming. When forested areas were historically cleared to create farmland, the ground was often washed away by rain. Consequently, small parcels of land were constructed with supporting stone walls, forming "poios", or terraces, up to an altitude of $700 \mathrm{mt}$., out of reach of ploughs and animals. These factors have traditionally made for heavy work and maintenance. The oldest "levadas" can be found on the south coast. From the mid-19th century, the state built longer levadas to take water from the mountains on the north side to be sold to farmers all over the island. During the 1940's and 1950's a new network of "levadas" was built, significantly increasing irrigation capacity and introducing hydro-electric power generation (Ornelas, 2007).

Economic activities, such as tourism have also contributed greatly to recent physical transformations taking place in the natural environment, impacting, often negatively, on the authentic image of the place (Norberg-Schulz, 1979; Canter, 1977; Mestre, 2002; Chaves, 2017).

In the 18th century Madeira became renowned as an exotic destination for wealthy tourists to spend mild winters and where tuberculosis sufferers were brought to receive treatment because of the supposed therapeutic virtues of the climate. In the 19th century, the spectacular landscapes and lush forests started to attract a new wave of visitors. Today tourism is the leading industry on the island in terms of revenue and the stunning natural landscape continues to attract millions of tourists from all over the world. In the last ten years the number of visiting tourists has been increasing exponentially. The mass tourism approach adopted on the island tends to favour investment in new big hotels, resorts, and infrastructures designed to accommodate more and more people. The island has benefited from this development on several levels, but there is little doubt that this model is unsustainable from both an environmental and socio-economic point of view. 


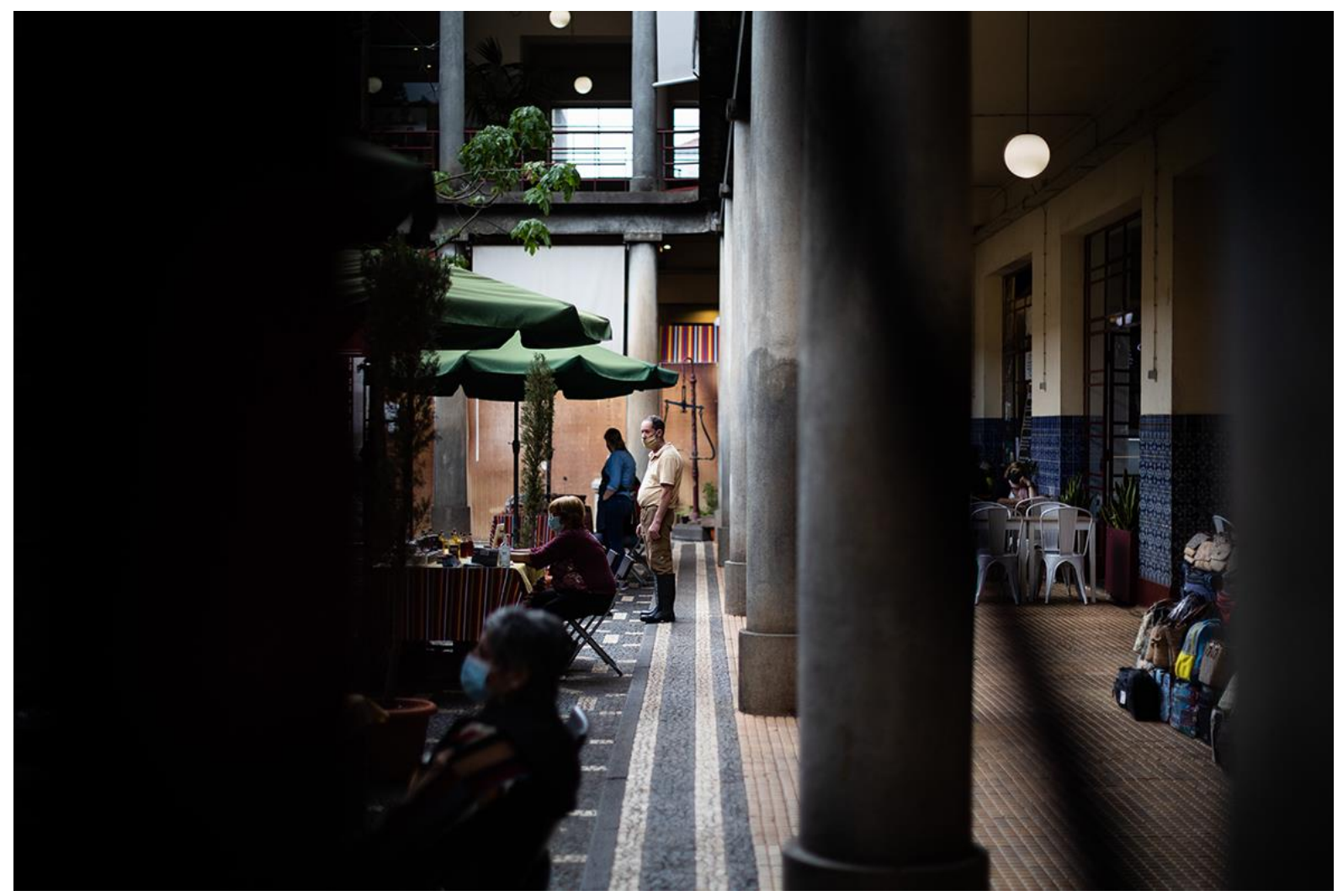

Figure 5. Waiting for the tourists. Mercado dos Lavradores, Funchal, May 2021. (Photo by Dan Brackenbury). The travel ban that happened all over the world due to the Covid-19 pandemic has revealed the fragility of Madeira's economy, which is highly dependent on mass tourism. According to Direção Regional de Estatística da Madeira (DREM), the number of visitors to the island rose from 1,028,723 in 2015 to 1.387.939 in 2019. Madeira has been awarded 'Best World Island Destination' by the World Travel Awards on various occasions since 2015. Such accolades have caught the attention of more and more tour operators, tourists and business investors. However, in 2020 DREM registered only 493.743 guests. This significant drop in numbers of visitors has deeply affected the tourism infrastructure and many people working in the local hospitality industry lost their jobs. Numerous small businesses had to close, leaving many buildings empty, a visible trace of a period of crisis and uncertainty.

The natural environment is regarded as Madeira's primary attractions list, followed by its cultural, historical and gastronomic heritage (Laboratorio Estratégico R.A. Madeira, 2016). Despite this level of importance, natural ecosystems, especially the endemic species, are under threat. Events that once were simply natural phenomena such as wildfires, floods and landslides are now more common, clearly a consequence of today's instable climate conditions. Progressive years of malfunctioning land management, including deforestation, introduction of aggressive species, abandonment of agricultural fields and rapid urbanization have permanently taken their toll on the island.

This lack of attention, care and respect toward the land and its natural resources caught our attention. In the process of organising the first Atlantic Wonder Summer School in 2018, we met many local experts, policy-makers, activists and researchers, all providing us with various, often conflicting ideas and opinions about how on the one hand nature should be 'left alone', and on the other hand how it should be 'assisted'. Morin (2017) highlights the risks of compartmentalising knowledge when dealing with wicked problems and complex challenges, such as those which can be seen to exist on Madeira. This is especially because the island is a small territory where politics and economic interests lead social conversations and influence both investment and research. There is fierce competition and disagreement surrounding environmental issues and therefore it is challenging to initiate a progressive conversation that allows for a plurality of opinions, particularly given the complexity of problems outlined above. 

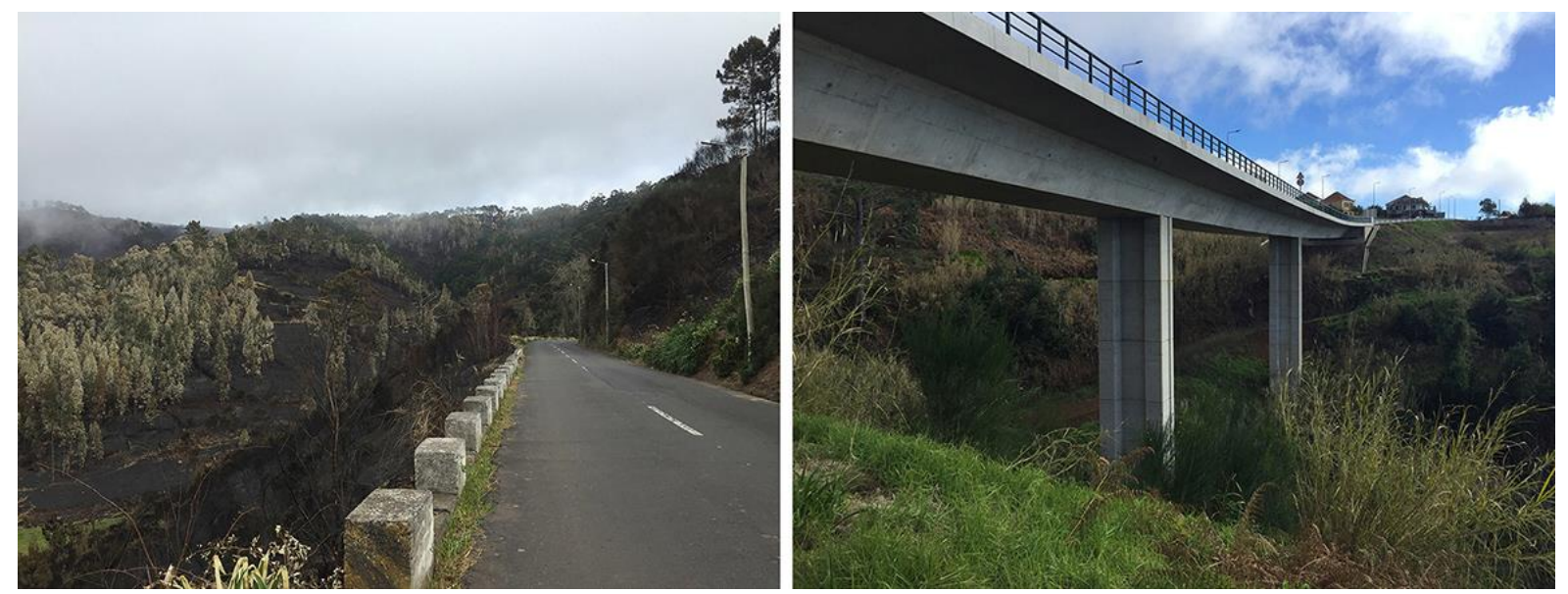

Figure 6. Left: Ponta do Pargo after the wildfire of February 2020. Right: the new highway from Prazeres to Ponta do Pargo in February 2021. In the warmer months the risk of wildfires is high, not just because of the dry, windy weather, but also due to plants that are extremely flammable. The most recent major wildfire occurred in 2016 when flames appeared on the mountain behind Funchal and quickly spread down to the city itself. In 2020 a large part of the forest in Ponta do Pargo, on the western edge of the island, burnt down leaving a black scar to remind us of the danger. In the last twenty years infrastructures such as highways and tunnels, and new large buildings, such as hotels and apartment blocks have populated the island.
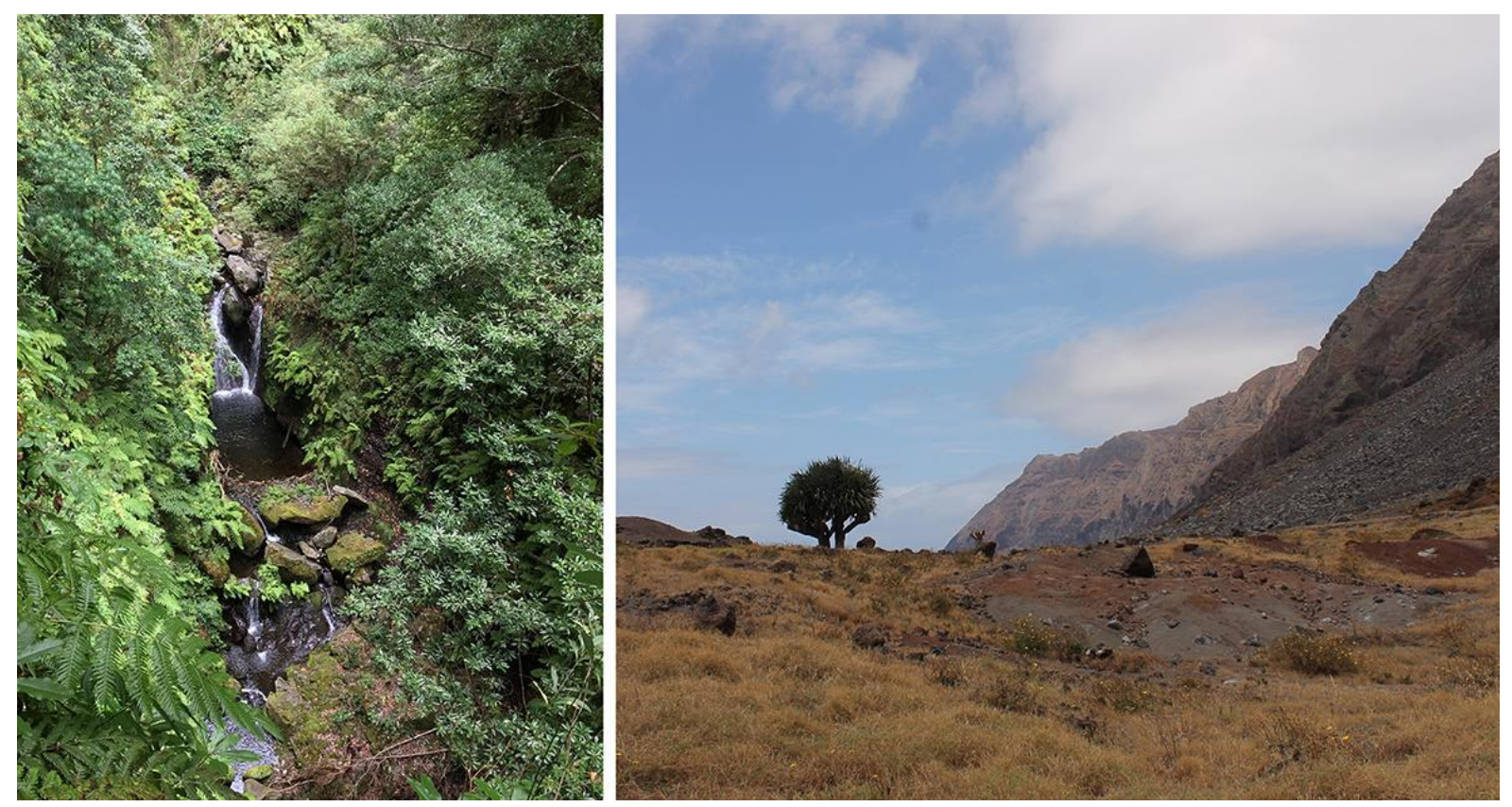

Figure 7. Right: a portion of ancient forest close to Sao Vincente, Madeira, where a new road will be built. The plan to construct a road crossing a portion of the Laurissilva is very controversial and has incited protests by local citizens and activists because the road would irreversibly damage a part of this ancient forest. However, the proposed road would also help to connect areas that otherwise are isolated. The question has arisen as to whether it is fully necessary for a road to be constructed in this area. Left: Desertas Islands (part of Madeira's Archipelago). Goats were introduced on these islands by sailors at the beginning of the 20th century and were mainly a source of meat for temporary visitors as well as Madeira's local inhabitants. These goats have caused the extinction of some endemic species. People were invited to hunt the goats in order to keep the numbers down but this plan was abandoned to due local objections. As a result, the population of these animals has grown beyond control (Sequeira et al, 2021). The need to take action to avert a further ecological crisis within the delicate island ecosystem clashes with the interest of those who want to protect these animals. In both these examples, we can observe the lack of access to in-depth information on complex development issues occurring locally. Meanwhile a community of citizens, activists and environmental associations is needed in order to communicate with the institutions responsible for local decision making and vice versa. This lack of social conversation about environment demonstrates the complexity of environmental matters occurring on the island and the various disciplinary interconnections between them. 


\section{Atlantic Wonder project: learning-by-walking and fieldwork as strategy to reconnect with nature}

The project Atlantic Wonder (AW) took shape in 2018 with the organisation of the first international summer school (AWSS18) on Madeira Island, with the idea that design can have a role in building bridges among the conflictual local debates and different points of view. Led by a team of researchers and educators from the Department of Art \& Design at the University of Madeira, today AW can be defined as a platform for multidisciplinary conversations and creative activities that reflect upon the relationship between design and nature. AW relies on the collaboration with international organisations, such as Paco Design Collaborative, and local institutions, such as IFCN The Regional Institute of the Forests and Nature Conservation, the Marine Biology Station and the Natural History Museum of Funchal.

Since its inception, AW has attracted to the island a diverse range of design practitioners, researchers, philosophers and artists to partake in dialogues with local natural scientists and designers. The intention was to build a common vocabulary and a set of tools for understanding nature, stimulate productive discussions between different disciplines and promote social dialogue with experts, citizens and policy-makers. This small island gives us the privileged position of testing some intuitions and working on a smaller scale. Both AWSS18 and AWSS19 summer schools and the teaching initiatives within the bachelor in Design at the University of Madeira have allowed us to start rooting locally a new conversation on nature and design, while connecting with the international debates, projects and research.
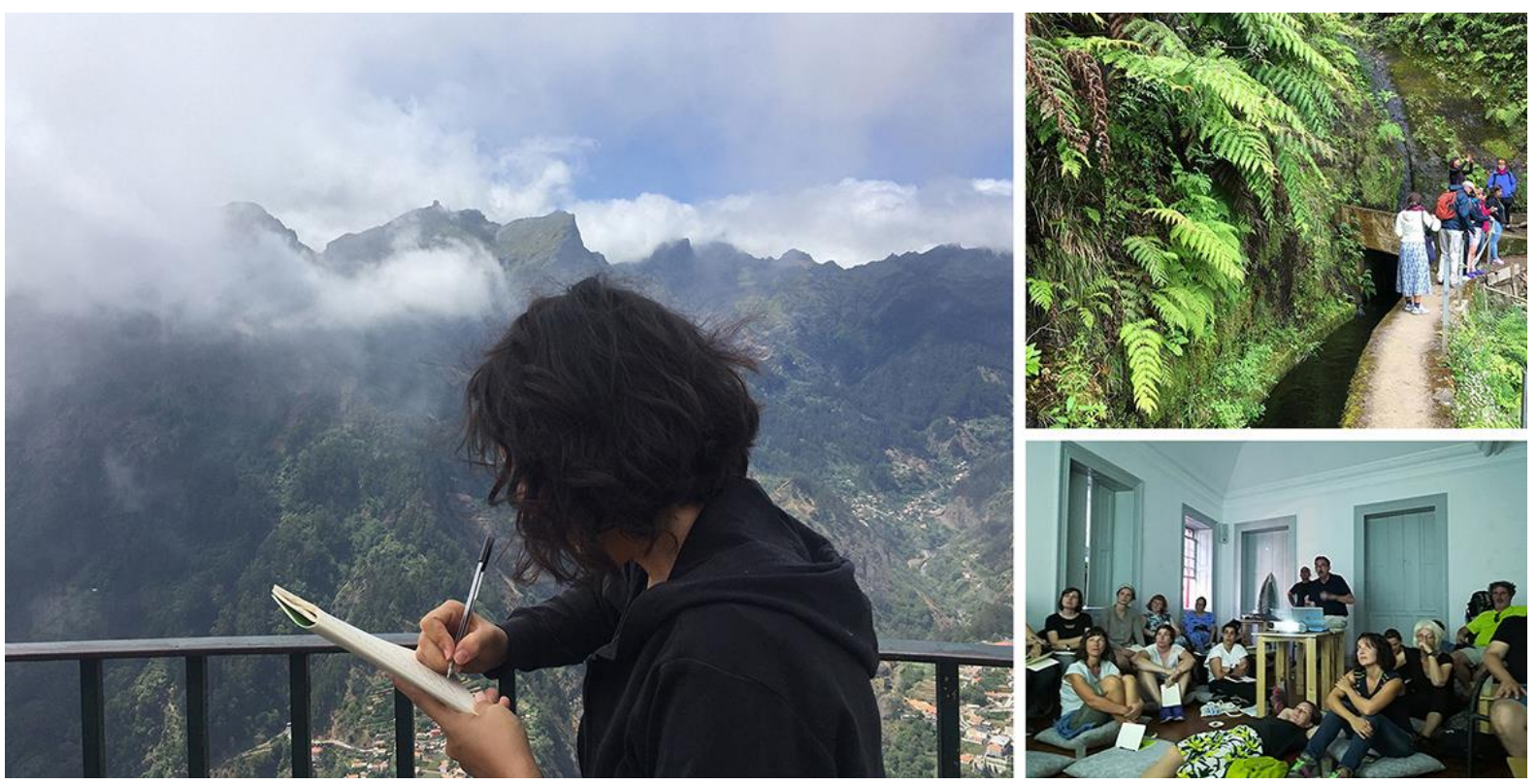

Figure 8. Images from the 2018 international summer school "AWSS18 - Atlantic Wonder. Exploring Nature \& Design in Madeira Island".

Teaching design in Madeira Island gives us the opportunity to experiment educational activities outdoors, trying to achieve a more complete learning experience for the local students. After a few years it is possible to acknowledge the benefits of organising visits to laboratories and archives, doing walks either through public gardens or mountain forests, meeting different types of expertise and discovering new research tools and languages. 
The activity of walking, particularly favourable on the island of Madeira, has been identified as a method to learn within a natural environment in an immersive way. In fact, walking has always been a form for humans to get to know the world (Solnit, 2000; Kagge, 2019) and continue to learn from it (Ingold and Vergunst, 2008). AW project got inspiration from the walking practice of many contemporary artists (Davila, 2002; Thompson, 2012), geographers (Pierce and Lawhon, 2015), designers and architects' research activities (Careri, 2006).

Taking walks in the outdoors also represents an opportunity for people with different backgrounds to engage with fruitful conversations, because by walking and talking, barriers break down and more disposition to listen actively and share can manifest. The learning-by-walking approach developed within the AW summer schools has involved biologists, art historians, designers, artists, researchers, professors and students.

Pierce and Lawhon (2015) define walking as a method that offers the opportunity for developing local literacy. In more general terms, walking is an embodied experience that allows us to learn about a place. In our case, the place is the island where the borders between the urban, the rural and the under-protection areas are not so visible and tangible.

It is embedded in our practice as designers to keep learning and training our capability of listening and observing what surround us. This is as much a theoretical work as it is poetic and practical. For this, the following references can be mentioned as inspiration and guidance to the field work approach developed within AW. The visual essay II Mare come artigiano by Bruno Munari (1992); Keri Smith's exercises (2008) inspired by exploratory practices of different artists; various publications by Planeta Tangerina, among which Là Fora (Peixe Dias et al., 2014) trying to encourage children to learn from nature; the poetic documentation of Amazonian craftsmanship by Andrea Bandoni (2012); the Deep Listening exercises by Pauline Oliveiros (2005).

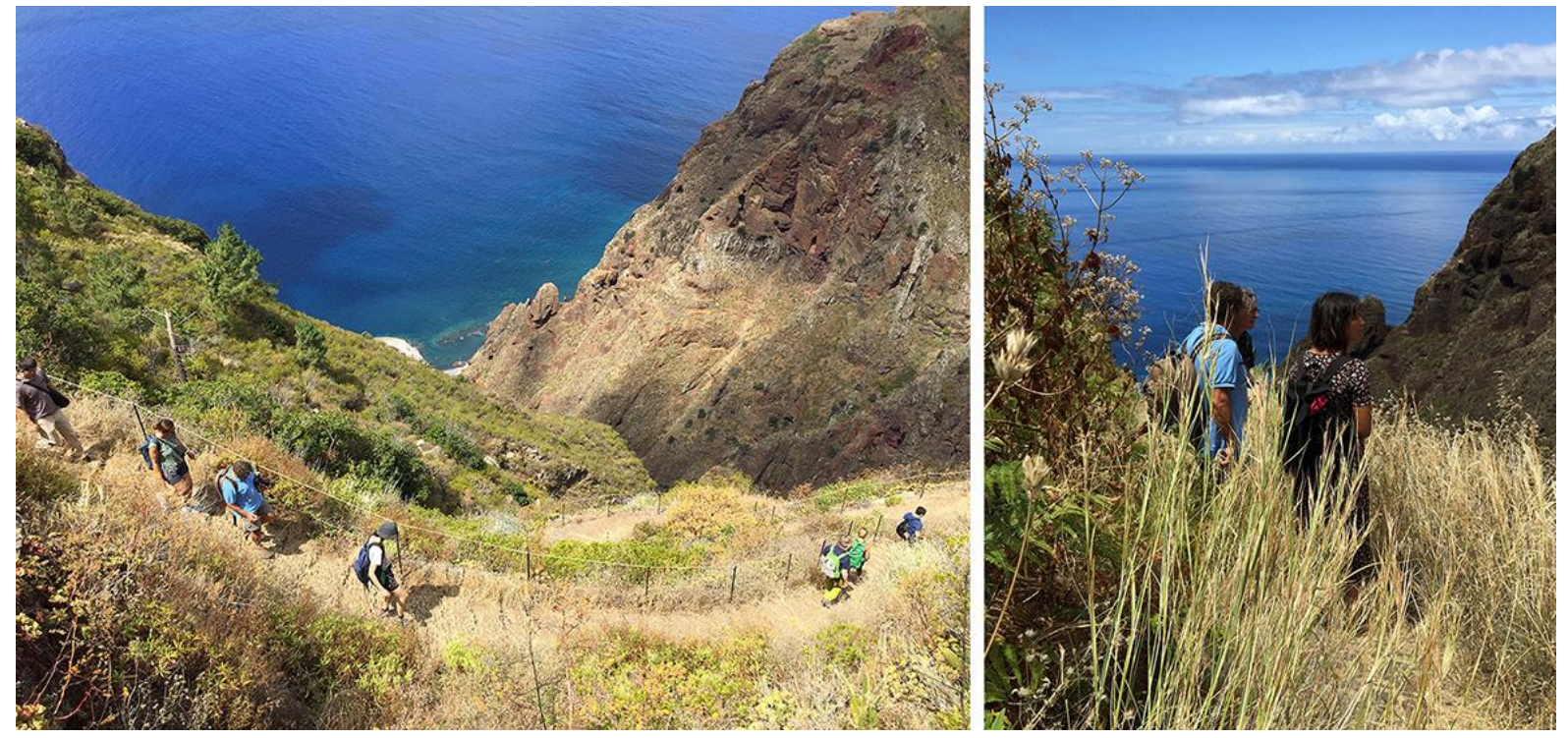

Figure 9. Learning-by-walking towards Paul do Mar (AWSS19). All the AWSS18 and AWSS19 walks were thought as an opportunity to explore the natural environment as well as a moment to actively engage with fruitful conversations with local experts in biology, botany and agronomy. The descent toward Paul do Mar, a small fishermen village on the south-western coast of the island, through the path called Camino Real, represented an opportunity for the participants and mentors to learn about 'rewilding'. This Camino Real crosses an area recently put under protection by the local authorities, and where now it is possible to witness the return of the native vegetation. The walk was led by Miguel Sequeira, a local botanist familiar with the rewilding process of this specific area of the island. The conversations that happened between the AWSS19's participants (such as, design historians, ecologists, designers) and Sequeira allowed us to imagine possible future sustainable scenarios and explore different "What Ifs...?". 


\subsection{AWSS19 - Design tools to observe and understand nature}

From the experience of the AWSS18 (Vezzani, Gonzaga, Bertolotti, 2019), we designed the AWSS19 programme by considering more time dedicated to walks and fieldwork, more moments of collective dialogue and self-reflection. Through immersive experiences and activities in nature and the guidance of local biologists, botanists and entomologists, both participants and mentors got to know better how to observe, analyse and understand natural ecosystems and some of the present living organisms. AWSS19 aimed to understand how the natural sciences can inform design thinking to ignite fruitful conversations and key questions before tackling complex themes such as sustainability or sustainable development. From the AWSS18 experience, we realised that it is necessary to reconnect with nature, understand ourselves - human beings - as participants of a complex system of interdependent organisms and habitats. Also, to exercise our capability of changing perspective, particularly considering the point of view and needs of other living beings.
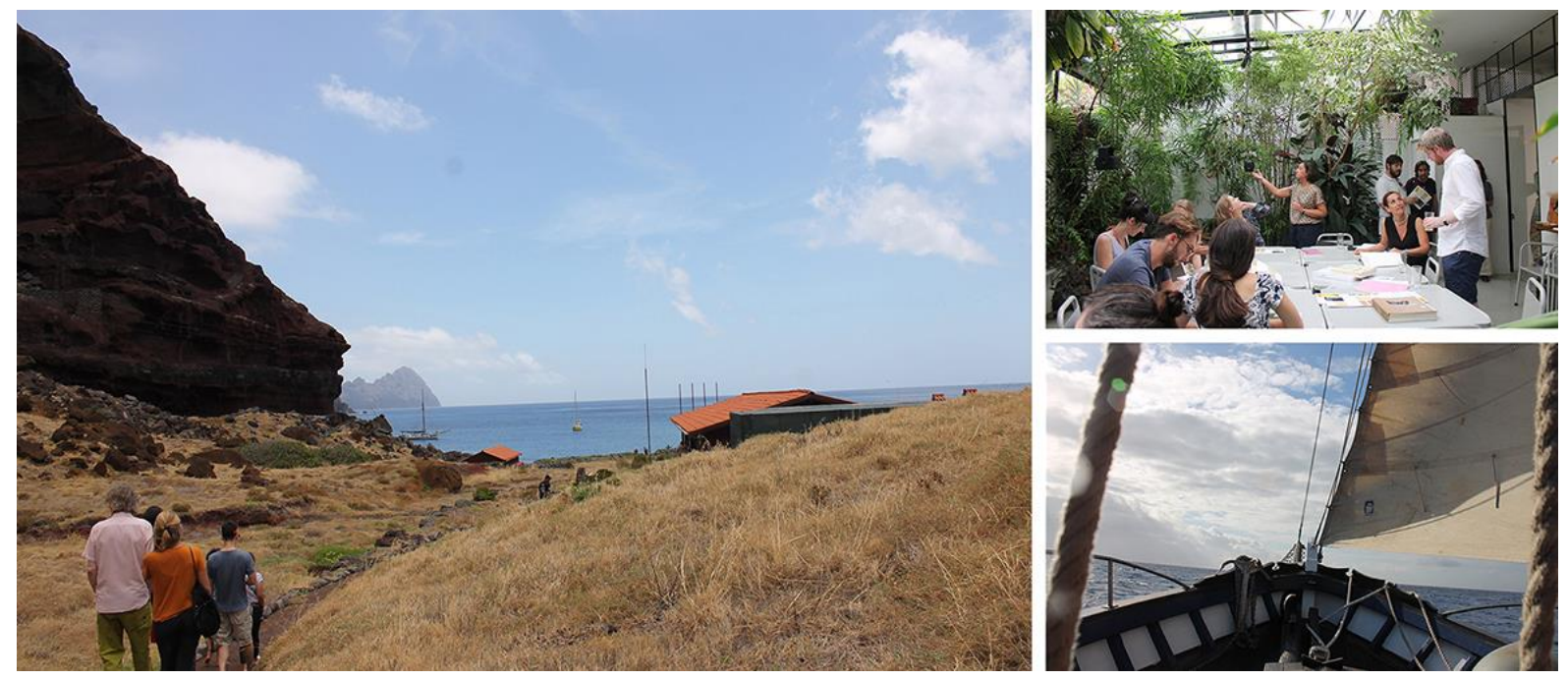

Figure 10. Images from the AWSS19 international summer school "Routes of Nature and Design on Madeira Island".

From the moment that we wanted to use the AWSS19 as an opportunity to listen and learn more from the natural sciences, we prepared a set of tools inspired both from biology and design, to learn about and from nature. We had meetings with the local experts invited to the summer school, to select the tools that they already use in their daily job of collecting, analysing and archiving specimens. We also let ourselves go with our own creativity by rethinking some of the popular design tools to speculate on the participants' capacity of changing perspective and embodying other kinds of organisms. Finally, among the invited mentors we called a Portuguese illustrator to inspire and support the participants in the activity of depicting the encountered plants, animals and landscapes through hand-sketching.

We prepared a portable field-book to provide both to participants and mentors with. It contained: (1) a detailed AWSS19 programme; (2) the tools we designed to support the fieldwork activities; (3) the maps of the areas and paths to explore. With a $15 \times 15 \mathrm{~cm}$ format, extractable pages and a different selection of blank pages for notes and drawings, we meant the field-book to be a personal diary to carry around during walks and meetings with the invited biologists. We wanted it to be a physical space where each person could record different kinds of information, using drawings and maps to visualise the complexity of themes and questions identified during the AWSS19 days. 

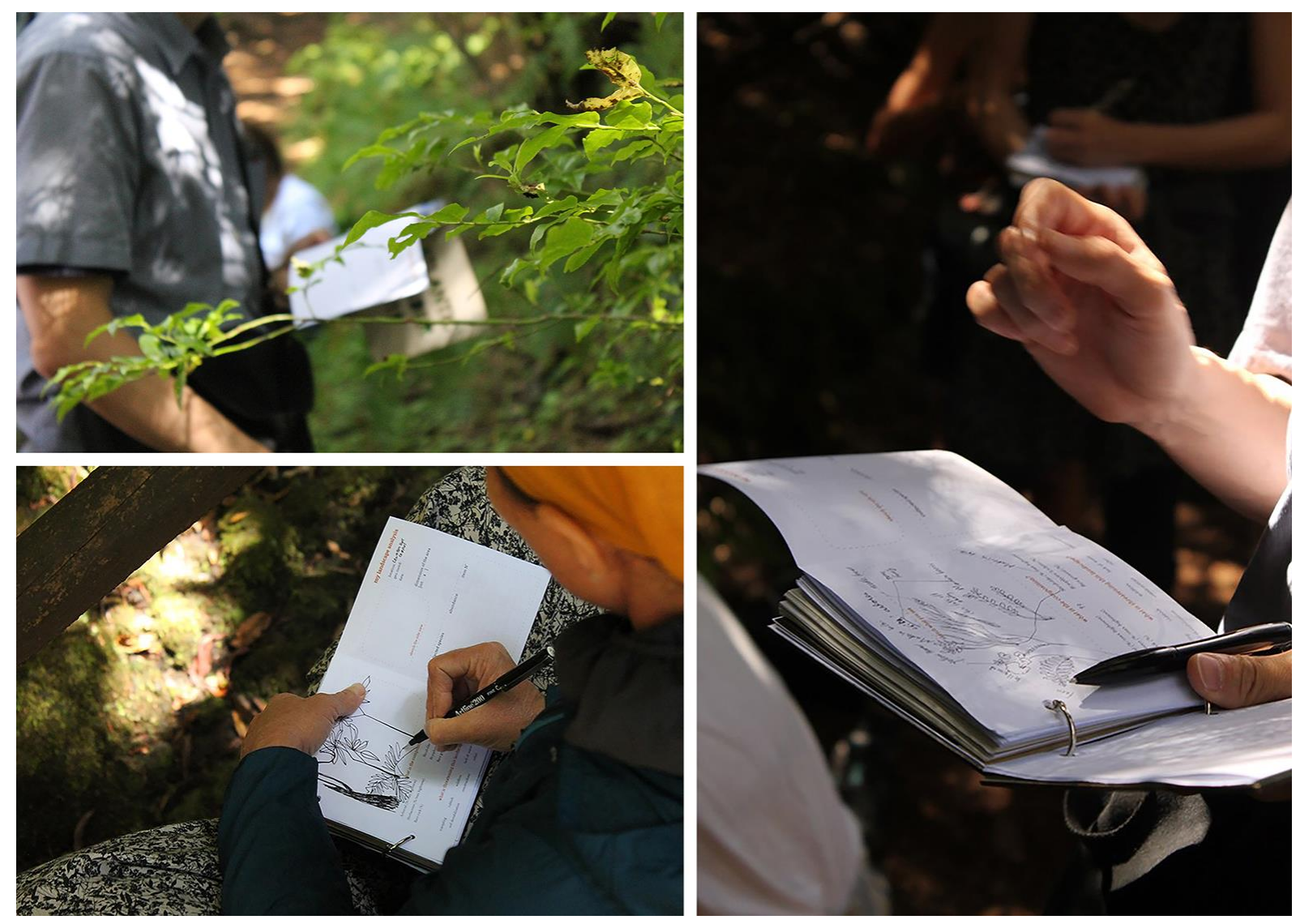

Figure 11. The AWSS19 field-book. During the walks through the Laurissilva and other natural areas under process of rewilding, both participants and mentors were encouraged to use tools like the 'My landscape analysis' and 'My plants collection' so that they could learn about how to collect a specimen and catalogue it with the assistance of botanists, biologists and entomologists leading the activity in the field.

Tools 1 - Presence and distribution tools: My landscape analysis; My plants collection; My organisms' collection; Distribution grid.

This group of tools serves the need of collecting data about living organisms and mapping their presence in a defined area or landscape. Inspired by existing formats used by natural scientists and biologists, they allow to document and record both vegetal and animal species. By using $M y$ landscape analysis and My plants collection, the participants, mentors and facilitators learnt how to observe and document the great variety of plant species present in just one-meter squared area. Being very clear with the information required to fill the layout in, they were somehow of inspiration for the participants who wanted to collect as many specimens as possible and learn about their characteristics. 


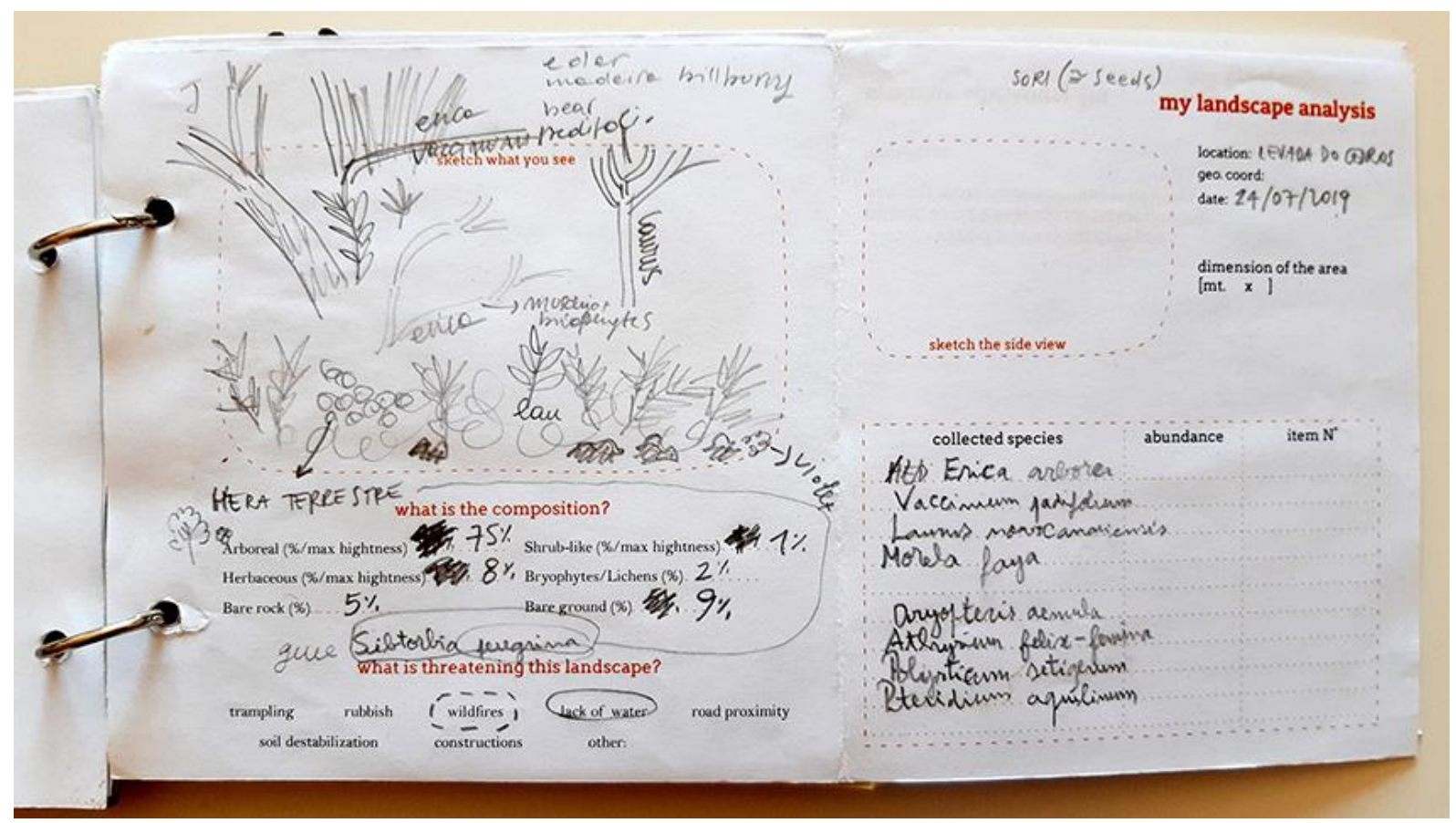

Figure 12. 'My landscape analysis' layout filled on field with the guidance of the botanist Juan Silva from the Natural History Museum of Funchal. This tool organises in a new visual way the basic information that biologists would use normally to catalogue a specimen.

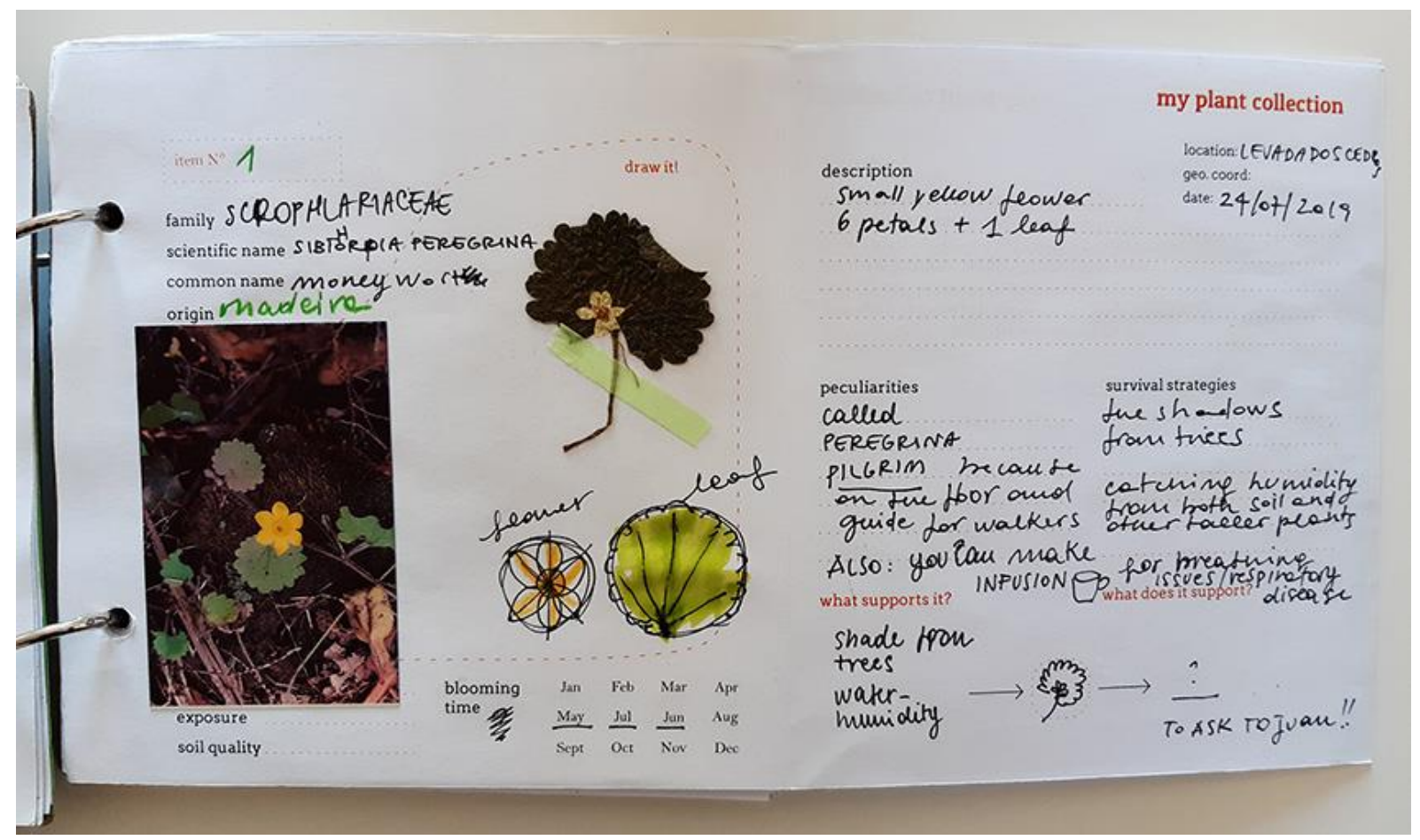

Figure 13. 'My Plants Collection' layout filled on field with the guidance of the botanist Juan Silva from the Natural History Museum of Funchal. This tool organises in a new visual way the basic information that biologists would use normally to catalogue a specimen.

\section{Tools 2 - Routes and fluxes tools: The journey of an organism; Migration map.}

This group of tools was thought to make the participants aware of the journeys that all organisms, either vegetal or animal, undertake in the course of time. And for journeys we meant both physical dislocation and gradual evolution changes. 
While the Migration Map is an existing tool used to map how and where specific species move to, the Journey of an organism was instead inspired by the Journey Map, a synthetic representation that describes step-by-step how a user interacts with a service (Service Design Tools, 2009). In this case, there is no user and no service, but there is an organism that undertakes a journey: it evolves, encounters other organisms, as well as threats and critical stages. The tool requires to shift the point of view and see both actions and results from the perspective of the selected organism. In the first line of boxes the sequence of events or actions must be drawn; then on the second line, notes on critical events and observations can be written. The last line is dedicated to track the health status of the organisms to highlight when and where the organism thrives or suffers.

The Journey of an organism aims to start exploring the concept of cause-effect that explains how each organism is interconnected with others and contributes either to the natural balance within an ecosystem or, on the contrary, to a specific equilibrium disruption.

\section{Tools 3 - Interrelations: Organisms map; Typologies analysis.}

This last group of tools was designed to better reflect on the complexity of interrelations existing between organisms and between the organisms and their habitat.

As the Journey of an organism, also the Organisms map takes inspiration from a design tool. Like an Ecosystem or Stakeholders map, this layout allows one to visualise a natural ecosystem from the perspective of a chosen organism - put at the centre of the scheme - while connecting it with other organisms and specific habitat characteristics. An Ecosystem Map usually captures all the key roles that have an influence on the user, organisation and service environment. First, all the entities must be displayed, then the connections between them representing the type of value they exchange must be traced (Service Design Tools, 2009). Again, there is no user here, but a living organism, together with other organisms, environmental elements and factors that allow it to thrive.

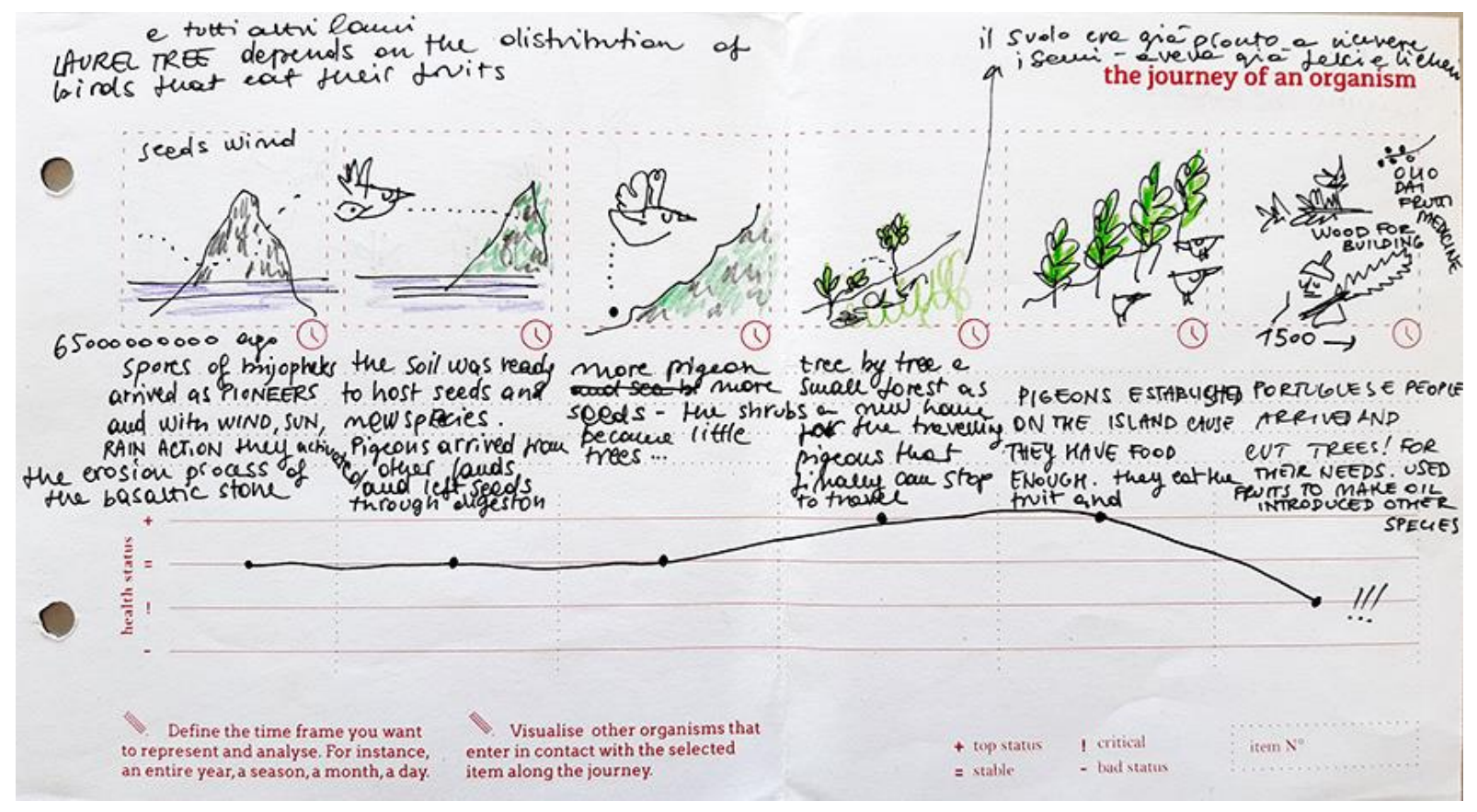

Figure 14. The 'Journey of an Organism' tool filled in with hand-sketches and some quick notes after learning about the role of some species in carrying seeds and pollens to the ancient island of Madeira. Here the Long-Toed Pigeon, one of the endemic species present in the Laurissilva, is the main character of a journey that tries to explain its role in the formation of the Laurissilva on Madeira. The 'health status' line at the bottom of the layout aims to visualise both the optimal and threatening conditions for this species to live and thrive. 


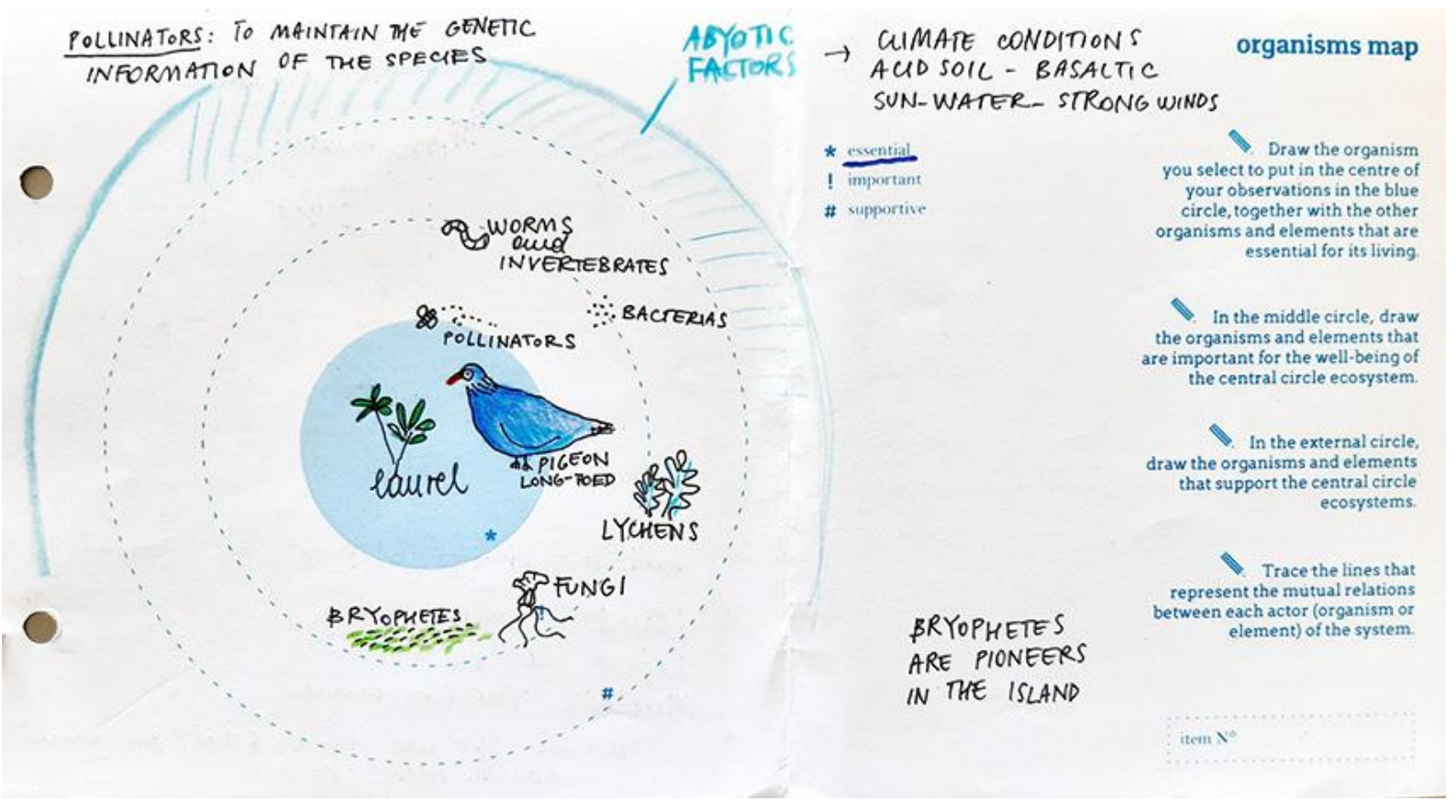

Figure 15. The 'Organism Map' tool filled in with the Long-Toed Pigeon as protagonist of the mapping process. This bird plays a fundamental role for the existence and resilience of the Laurissilva forest, but its job could be pointless without the presence and efforts by other organisms and right climate conditions.

\section{Discussion and final considerations}

The whole AWSS19 experience impacted positively both on the participants, mentors and local experts, and provided useful insights to develop an interdisciplinary mindset and approach towards sustainable development. However, our intention of testing the tools during the programme and getting sufficient data to validate their usefulness had to be put aside. Unfortunately, we learnt that the summer school programme was too dense of activities and types of insights. Both participants and mentors expressed the need of dedicating more time to understand and use most of the tools. Those belonging to the first group, though, received more attention. For instance, My landscape analysis and My plants collection were relatively easy to complete and somehow motivating for the participants to learn about as many species as possible and expand their own collection. On the contrary, those elaborated tools, such as the Journey of an Organism and the Organism Map required more thinking to strategically organise the necessary information and time to draw.

The attempt of testing both the quality and usefulness of the field-book and tools has taught us that in order to learn about a place, landscape or ecosystem, it is necessary to dedicate time, presence, perseverance, as also find guidance by those who hold competence and knowledge.

On another positive side, both participants and mentors demonstrated willingness in personalising their field-book with their own notes and quick sketches. As a visual memory of the whole AWSS19 experience, the field-book represented to them a place where to return to, to rediscover the various learnings and re-use the offered tools for new contexts and habitats. On the other hand, the biologists that accompanied the walks and activities in the field, considered both the Journey of an Organism and the Organisms Map quite surprising tools. We were seeking a way to open a new type of conversation with the scientists and surely the application of some visualisation strategies proper of the design field allowed us to create a bridge with the natural sciences. Our invited experts discovered some new opportunities to talk about the complexity of interrelations existing in nature. 
For instance, thanks to the way we could use a sequence of simple images to tell a story from the perspective of one chosen species, or map the relationships existing among different living organisms present in the same ecosystem and highlight the interdependence between species and their habitat. Tools like the Journey of an Organism and the Organisms Map inspired an exercise of changing perspective, going beyond the human needs only. By giving priority to one species and its needs or another, we can speculate on various scenarios that might happen; for instance, some environmental factors could be different and/or one organism could be missing from the ecosystem. Training the capability of changing perspective can help in becoming more aware of what sustainability means.

Sure of the potential of using these tools to enhance fruitful dialogue among people from different fields of study and professional experiences, we are planning to test each tool by organising tailored activities in the field. Given the current pandemic situation, we have decided to pause our research until when we are able to gather a significant number of participants and experts to experience new collective learning activities in the forest in safety.

While we wait for better times, AW approach is used in our teaching at the Bachelor in Design at University of Madeira by challenging future designers - particularly those living on the island - in observing problems from multiple perspectives. For instance, through small projects in collaboration with the Natural History Museum, the Marine Biology Station of Funchal and the University of Madeira Botany Group, we provide our students with opportunities to learn how to dialogue with the sciences and exercise their ability in mediating complex and technical information for a more general public.

Finally, in the context of the AW summer schools, walking represents a learning method where one can experience the natural environment with all senses, interact with other people through informal conversations and open up to other disciplines, key questions and observations that probably couldn't have happened otherwise. Also, the walking and fieldwork experiences we have run till now are still sporadic. If repeated on a more regular basis, documented, analysed and compared, they could actually represent a common background for evaluating the credibility of the walking method (Pierce and Lawhon, 2015).
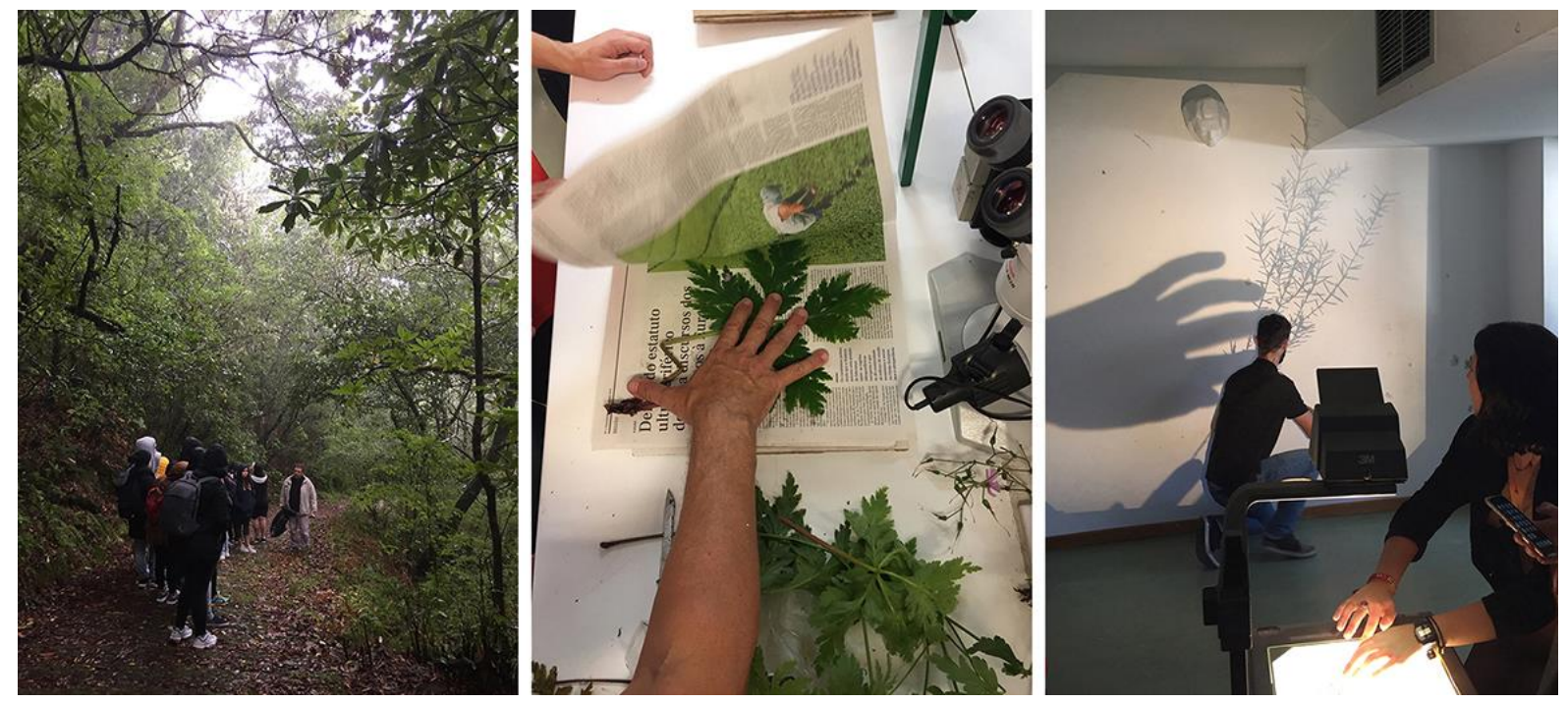

Figure 16. Design projects in collaboration with prof. Miguel Sequeira and the University of Madeira Botany Group in 2019. This collaboration brought the design students to investigate and learn about how to identify the different botanical species present in the Laurissilva. 
Walking, sharing and discussing, observing are core activities within the AW project. Our research work starts from a personal need of learning. We felt that our experience and basic training as designers was not sufficient for the contemporary challenges and debates concerning the relationship between design and nature. We felt that the points of view from which we started had to be questioned, and many of the words we were using had to be understood and contextualized better, among which: nature, ecology, sustainability, sustainable development, social innovation.

Madeira presents most of the problems and challenges that any other spot in the world is facing today regarding sustainable development, but islands are fragile territories. Their natural environment needs further attention and protection, because the extinction of species happens more frequently than on vast lands and the equilibrium of ecosystems can be easily disrupted.

Due to the fact that it is an autonomous region and confined territory, Madeira allows us to explore and map from multiple perspectives the complexity of certain issues regarding sustainable scenarios. It is possible to test methods and tools that can enhance positive conversations and actions towards sustainable practices. Also, that would allow us to speculate on not too far futures where the island represents the test-bed for inclusive, fair and resilient solutions for nature and all its elements and organisms, among which human beings too.

\section{References}

Bandoni, A. (2012). Objetos da Floresta. Explorando a Amazônia através do olhar de designers [Objects of the Forest. Exploring the Amazon through designers' eyes]. São Paulo: Andrea Bandoni de Oliveira.

Boehnert, J. (2018). Design, Ecology, Politics: Towards the Ecocene. London: Bloomsbury Academic. Breidbach, O., Vercellone, F. (2010). Pensare per immagini. Tra scienza e arte. Milano: Mondadori. Braidotti, R. (2019). Posthuman Knowledge. Cambridge: Polity Press.

Bonney, R., Cooper, C.B., Dickinson, J., Kelling, S., Phillips, T., Rosenberg, K. V., Shirk J. (2009). Citizen Science: A Developing Tool for Expanding Science Knowledge and Scientific Literacy. BioScience, 59(11), 977-984.

Bruni, R. (2018). Mirabilia. La botanica nascosta nell'arte. Torino: Edizioni Codice.

Canter, D. (1977). The Psychology of Place. London: The Architectural Press Ltd.

Careri, F. (2006). Walkscapes. Camminare come pratica estetica. Torino: Einaudi.

Ceschin, F., Gaziulusoy, I. (2016). Evolution of design for sustainability: From product design to design for system innovations and transitions. Design Studies, 47, 118-163. Retrieved at: https://doi.org/10.1016/j.destud.2016.09.002

Chaves, D. N. (2017). Açores e Madeira : percursos de memória e identidade / coord. Duarte Nuno Chaves. São Jorge, Açores : Misericórdia das Velas.

Coccia, E. (2020). Métamorphoses. Paris: Rivages.

Davila, T. (2002). Marcher, Créer. Déplacements, flâneries, dérives dans l'art de la fin du XX siècle. Paris: Regard.

de Vries, M., Land-Zandstra, A. and Smeets, I., 2019. Citizen Scientists' Preferences for Communication of Scientific Output: A Literature Review. Citizen Science: Theory and Practice, 4(1), 2. Retrieved at: http://doi.org/10.5334/cstp.136

Descola, P. (2010). Diversité des natures, diversité des cultures. Paris: Bayard, collection Les petites conférences. 
Dickinson, JL, Shirk, J, Bonter, D, Bonney, R, Crain, RL, Martin, J, et al. (2012). The current state of citizen science as a tool for ecological research and public engagement. Frontiers in Ecology and the Environment, 10(6), 291-297. Retrieved at: https://doi.org/10.1890/110236

Edensor, T. (2010). Walking in rhythms: Place, regulation, style and the flow of experience. Visual Studies, 25, 69-79.

Escobar, A. (2018). Designs for the Pluriverse: Radical Interdependence, Autonomy, and the Making of Worlds. Durham: Duke University Press.

Gaziulusoy, I, Veselova, E., Hodson, E., Berglund, E., Erdoğan Öztekin, E., Houtbeckers, E., Hernberg, H., Jalas, M., Fodor, K. \& Ferreira, M. (2021). Design for Sustainability Transformations: A Deep Leverage Points Research Agenda for the (Post-)pandemic Context. Strategic Design Research Journal. 14, 01, 19-31. Retrieved at: https://doi.org/10.4013/sdri.2021.141.02

Haraway, D. (2016). Staying with the Trouble. Making Kin in the Chthulucene. Durham and London: Duke University Press.

Ingold, T. \& Vergunst, J. (eds.) (2008). Ways of Walking: Ethnography and Practice on Foot. Ashgate: Aldershot.

Kagge, E. (2019). Walking: One step at a time. New York: Knopf Doubleday.

Laboratorio Estratégico R.A. Madeira (2016). Estratégia Turismo 2027 Portugal. Retrieved at: www.turismodeportugal.pt/SiteCollectionDocuments/estrategia/LET-Madeira-ET2027.pdf

Latour, B. (2018). Down to Earth: Politics in the New Climatic Regime. England: Polity Press.

Latour, B. (2021). Où suis-je? Leçons du confinement à l'usage des terrestres. Paris: La Découverte.

Mancuso, S. (2019). La Nazione delle Piante. Roma: Laterza.

Matos, R. C. (2013). As Origens do Turismo na Madeira - Quintas e Hotéis do Acervo da Photographia Museu - «Vicentes». Funchal: Delegação Regional da OE e DRAC.

Morin, E. (2017). Connaissance, Ignorance, Mystère. Paris: Fayard.

Morin, E. (2020). L'entrée dans l'ère écologique. Paris: Editions de l'Aube.

Mestre, V. (2002). Arquitectura popular da Madeira. Lisboa: Argumentum.

Munari, B. (1992). Il Mare come artigiano. Mantova: Corraini.

Norberg-Schulz, C. (1979). Genius loci: paesaggio, ambiente, architettura. Milano: Electa.

Oliveros, P. (2005). Deep Listening: A Composer's Sound Practice. New York: iUniverse

Ornelas, P. (2007). Madeira. A short illustrated history. Funchal: Madeira Story Centre.

Fernández-Palacios, J.M., Arévalo, J.R., Balguerías, E., Barone, R., Nascimento, L., Delgado, J.D., Elias, R.B., Fernández-Lugo, S., Méndez, J., Menezes de Sequeira, M., Cigala, A. Naranjo, Otto, R. (2018). La Laurisilva. Canarias, Madeira y Azores. Santa Cruz de Tenerife: Macaronsesia Editorial.

Peixe Dias, M. A., Texeira Do Rosario, I., Carvalho, B. P. (2014). Lá fora. Guia para descobrir a natureza. Porto: Planeta Tangerina.

Pierce, J., Lawhon, M. (2015). Walking as Method: Toward Methodological Forthrightness and Comparability in Urban Geographical Research. The Professional Geographer, 67(4).

Puig de la Bellacasa, M. (2017). Matters of care: speculative ethics in more than human worlds, Posthumanities. Minnesota: University of Minnesota Press.

Rancière, J. (2008). Le Spectateur émancipé. Paris: La Fabrique.

Raworth, K. (2017). Doughnut economics: seven ways to think like a 21st century economist. London: Penguin Random House.

Sequeira, M. et al (2021). Population decline in the Critically Endangered Musschia isambertoi(Campanulaceae) endemic to Desertas Islands (Madeira Archipelago) calls for urgent conservation management. Journal for Nature Conservation, 60.

Smith, K. (2008). How to Be an Explorer of the World: Portable Art Life Museum. New York: Peregee. 
Solnit, R. (2000). Wanderlust. New York: Penguin.

Star, S., Griesemer, J. (1989). Institutional Ecology, 'Translations' and Boundary Objects: Amateurs and Professionals in Berkeley's Museum of Vertebrate Zoology, 1907-39. Social Studies of Science, 19(3), 387-420.

Stickdorn, M., Schneider, J. (2013). This is service design thinking. Basics, Tools, Cases. Amsterdam: BIS Publishers.

Sziemer, P. (2010). Madeira's natural history in a nutshell. Funchal: Francisco Ribeiro \& Filhos.

Tassi, R. (2020). Service Design Tools https://servicedesigntools.org/tools

Thompson, N. (2012). Living as Forms. Socially Engaged Art from 1991-2011. Cambridge: MIT Press

Tsing,A. (2015). The Mushroom at the End of the World: On the Possibility of Life in Capitalist Ruins. Princeton University Press.

Van Maanen, J. (2011). Tales of the field: On writing ethnography. University of Chicago Press.

Vezzani, V., Gonzaga, S., Bertolotti, E. (2019). Atlantic Wonder. Exploring Nature and Design in Madeira island. Design Journal, 22: sup1, 1603-1617.

Wahl, D. C. (2009). Beyond Sustainability: Natural Design and Resilience. In Proceedings of the 8th European Academy of Design Conference. Aberdeen. Retrieved July, 2018 at: www.academia.edu/3991368/Beyond Sustainability Daniel Christian Wahl European Academy of Design Conference Aberdeen 2009

Walker, S. (2017). Design for Life. Creating meaning in a distracted world. New York: Routledge.

Author Bios:

Elisa Bertolotti, PhD in Design, Assistant Professor in Design, University of Madeira. Multimedia researcher and practitioner, her theoretical and practice-based research investigates the encounter between different disciplines, where communication design meets stories, drawings and moving images.

Valentina Vezzani, PhD in Design, Assistant Professor in Design, University of Madeira, and Co-founder of Paco Design Collaborative. She is involved in several research activities and projects concerning design education, service design, collaborative processes, design for social sustainability and social innovation.

Acknowledgements: First of all, thanks to the local biologists who helped us to develop and use the tools in the field; in particular, Juan José Gonçalves Silva, Ysabel Margarita Amaro Gonçalves and Miguel Sequeira. Thanks to the organisations which made AWSS19 programme possible: the Natural History Museum and Marine Biology Station of Funchal; the University of Madeira Botany Group; IFCN - The Regional Institute of the Forests and Nature Conservation; Quinta de Santa Luzia; PORTA33; Paco Design Collaborative. Thanks to our colleague Dr Susana Gonzaga who has been working with us on the AW project since its start. Thanks to all the AWSS19 participants and mentors who used the field-book and provided their initial feedback on the tools. In particular, Alastair Fuad-Luke, Gabriele Oropallo, Vanessa De Luca, Joana Estrela. And finally, thanks to Marco Antunes for his help in documenting the AWSS19 days. 